\title{
Editorial
}

\section{Controversies in vaccination scene in India}

\author{
Samir A. Singru* \\ Department of Community Medicine, Smt Kashibai Navale Medical College and General Hospital, Narhe, Pune-41, \\ Maharashtra, India \\ *Correspondence: \\ Dr. Samir A. Singru, \\ E-mail: psmsamir@gmail.com
}

(C) 2014 Singru SA. This is an open-access article distributed under the terms of the Creative Commons Attribution Non-Commercial License, which permits unrestricted non-commercial use, distribution, and reproduction in any medium, provided the original work is properly cited.

The current vaccination scene is marred by controversies and conflicts. In the absence of clear-cut policies, hardcore evidence, and lack of transparency in dealing with international agencies and donors, industry, academic bodies, and the media, the public health establishments dealing with vaccination are under unprecedented pressure from different quarters. Their policies are criticized by experts, openly questioned by the media, and dragged to the court by an emerging coterie of disbelievers often described as 'anti-vaccine activists'. The government also seems a bit confused and scared to take head on these groups mainly fearing judicial intervention and their adverse decisions. ${ }^{1}$ In the developing country like India, Immunization is broadly carried out by Government agencies and Private paediatricians and general practitioners. The Government agencies follow the national immunization schedule as recommended by the National Technical Advisory Group on Immunization (NTAGI) on behalf of Government of India which is meant for mass strategy. Similarly majority of the private practitioners and paediatricians follow the guidelines recommended by Indian Academy of Paediatrics (IAP) which are meant for individual strategy for office practice. There are certain differences in the guidelines issued by these two bodies and caregivers do find themselves in confusion in certain situations. However in the recent two years certain changes have taken place and the National Technical Advisory Group on Immunization (NTAGI) has recommended for introduction of another dose of measles vaccine at 18 months of age. IAP since many years was recommending second dose of Measles vaccine as Measles Mumps and Rubella (MMR) vaccine. In 2011, Government of India recently universalized Hepatitis B vaccination to all States/UTs in the country. IAP also recommended Hepatitis B vaccine since many years. As per the universal immunization schedule previously it was recommended to give DT vaccine at the age of four and half years of age. However in the light of the epidemiological shift of age group of pertussis as observed by cases of pertussis in four to five years of age, the schedule now recommends DPT vaccine at five years of the age. IAP was recommending DPT at five years of age since many years. There is an urgent need that these two apex advisory group should interact and give consensus recommendations.

Recently there was a controversy associated with pentavalent vaccines following the deaths of few beneficiaries in Kerala. However the National Adverse events following immunization (AEFI) committee in its report in September 2013 in the country clarified that the deaths reported in Kerala in the last year, after due investigation, were found as not related to the pentavalent vaccine. The government now plans to introduce pentavalent vaccines throughout the country. However some experts state the combination of DPT with hepatitis $\mathrm{B}$ raises the price of DPT immunization 17 fold. Moreover, the relative safety and efficacy of these cocktail combinations are much lower than their individual counterparts. ${ }^{2-4}$ There is definite confusion in between our experts and the beneficiaries at large.

The last polio case in the country was reported from Howrah district of West Bengal with date of onset $13^{\text {th }}$ January 2011. Thereafter no polio case has been reported in the country $\left(25^{\text {th }}\right.$ May 2012). WHO on $24^{\text {th }}$ February 2012 removed India from the list of countries with active 
endemic wild polio virus transmission. ${ }^{5}$ IAP has already recommended Inactivated Polio Virus (IPV) vaccine and many children are already vaccinated with IPV in private sector. The government agencies and its beneficiaries are waiting for the guidelines from their apex advisory group.

The recent IAP committee on immunization (IAPCOI) recommends offering human papillomavirus (HPV) vaccine to all females of age group of 10-12 years. ${ }^{6}$ There are controversies associated with HPV vaccine also. In Canada, USA and other European countries, the religious organizations and conservative political organizations often hold conservative view towards HPV vaccine and have questioned the national HPV immunization campaign. Similarly the beneficiaries also feel that they have not taken the vaccine and also will not take in future because of the fear that spouse, family or community at large will view them as promiscuous. ${ }^{7}$ Moreover the risk of cancer associated with the HPV virus is very low. The objections raised by experts are "Is it really justifiable to coerce mass populations of children to have HPV vaccination, particularly as the long-term consequences of the HPV vaccine are unknown?"

In a recent study regarding the working of the cold chain system in India as seen in state, regional and district vaccine stores and peripheral health facilities, respectively, the temperatures in the boxes exceeded $8^{\circ} \mathrm{C}$ for $14.3 \%, 13.2 \%, 8.3 \%$ and $14.7 \%$ respectively of their combined storage times and fell below $0^{\circ} \mathrm{C}$ for $1.5 \%$, $0.2 \%, 0.6 \%$ and $10.5 \%$ of these times. The boxes also spent about $18 \%$ and $7 \%$ of their combined times in transit at below 0 and above $8^{\circ} \mathrm{C}$, respectively. In shake tests conducted at the end of the study, two thirds of the vaccine vials in the boxes showed evidence of freezing. ${ }^{8}$ If this is the situation in the state, regional and district health facilities, what will be the situation at primary health centre (PHC) or sub centre which is the actual site of vaccination.

These are few examples from our current vaccination scene in India. There is a definite need to resolve these issues and clear the controversies associated with various vaccines in India.

\section{REFERENCES}

1. Bansal CP. IAP's perspectives on current vaccination scenario in India. Indian Pediatr. 2013 Oct;50(10):911-2.

2. Food and Drug Administration. Guidance for Industry for the Evaluation of Combination Vaccines for Preventable Diseases: Production, Testing and Clinical Studies. Washington DC: US Department of Health and Human Services, Food and Drug Administration, Center for Biologics. Eval Res, April 1997, Docket No. 97N-0029.

3. Buttery JP, Riddell A, McVernon J, Chantler T, Lane L, Bowen-Morris J, et al. Immunogenicity and safety of a combination pneumococcalmeningococcal vaccine in infants: a randomized controlled trial. JAMA 2005;293:1751-8.

4. Wouter H. Who can be confident about multiple vaccines in infancy? BMJ, 22 ${ }^{\text {nd }}$ April 2006, Rapid Response for Banatvala et al, hepatitis B immunization in Britain: time to change? 2006, $8^{\text {th }}$ April, $332 \quad$ (7545) 804-5. Available at http://www.bmj.com/cgi/eletters/332/7545/804\#132 291. Accessed 5 May 2014.

5. India officially removed from the list of polioendemic countries. Available at http://new.paho.org/hq/index.php. Accessed 6 May 2014.

6. IAP Committee on Immunization 2009-2011. IAP Guide Book on Immunization, 2011. Available at http://www.iapindia.org/files/IAP\%20Immunization \%20Guide\%20Book_2009_2010.pdf. Accessed 6 May 2014.

7. Friedman AL, Shepeard H. Exploring the knowledge, attitudes, beliefs, and communication preferences of the general public regarding HPV: findings from CDC focus group research and implications for practice. Health Educ Behav. 2007 Jun;34(3):471-85.

8. Murhekar MV, Dutta S, Kapoor AN, Bitragunta S, Dodum R, Ghosh P, et al. Frequent exposure to suboptimal temperatures in vaccine cold-chain system in India: results of temperature monitoring in 10 states. Bull World Health Organ. 2013 Dec 1;91(12):906-13.

DOI: 10.5455/2349-3291.ijcp20140501

Cite this article as: Singru SA. Controversies in vaccination scene in India. Int J Contemp Pediatr 2014;1:1-2. 